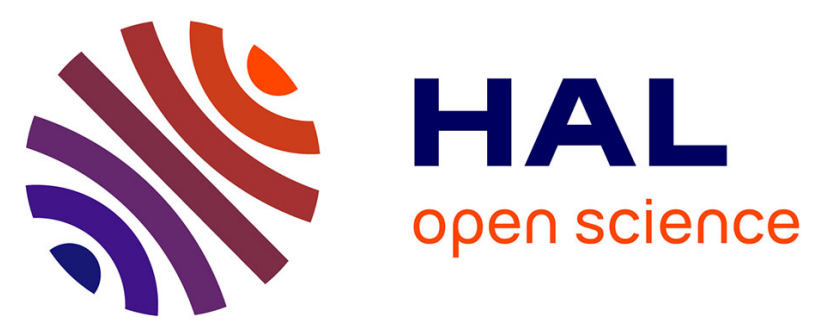

\title{
Effect of a condolence letter on grief symptoms among relatives of patients who died in the ICU: a randomized clinical trial
}

Nancy Kentish-Barnes, Sylvie Chevret, Benoit Champigneulle, Marina Thirion, Virginie Souppart, Marion Gilbert, Olivier Lesieur, Anne Renault, Maité Garrouste-Orgeas, Laurent Argaud, et al.

\section{To cite this version:}

Nancy Kentish-Barnes, Sylvie Chevret, Benoit Champigneulle, Marina Thirion, Virginie Souppart, et al. Effect of a condolence letter on grief symptoms among relatives of patients who died in the ICU: a randomized clinical trial. Intensive Care Medicine, 2017, 43 (4), pp.473-484. 10.1007/s00134-0164669-9 . hal-01783552

\section{HAL Id: hal-01783552 \\ https://hal.science/hal-01783552}

Submitted on 18 Dec 2019

HAL is a multi-disciplinary open access archive for the deposit and dissemination of scientific research documents, whether they are published or not. The documents may come from teaching and research institutions in France or abroad, or from public or private research centers.
L'archive ouverte pluridisciplinaire HAL, est destinée au dépôt et à la diffusion de documents scientifiques de niveau recherche, publiés ou non, émanant des établissements d'enseignement et de recherche français ou étrangers, des laboratoires publics ou privés. 


\title{
Effect of a condolence letter on grief
}

\section{symptoms among relatives of patients who died in the ICU: a randomized clinical trial}

Nancy Kentish-Barnes' ${ }^{1}$, Sylvie Chevret ${ }^{2}$, Benoît Champigneulle ${ }^{3}$, Marina Thirion ${ }^{4}$, Virginie Souppart ${ }^{1}$, Marion Gilbert ${ }^{5}$, Olivier Lesieur ${ }^{6}$, Anne Renault ${ }^{7}$, Maïté Garrouste-Orgeas ${ }^{8}$, Laurent Argaud ${ }^{9}$, Marion Venot ${ }^{10}$, Alexandre Demoule ${ }^{11}$, Olivier Guisset ${ }^{12}$, Isabelle Vinatier ${ }^{13}$, Gilles Troché $^{14}$, Julien Massot ${ }^{15}$, Samir Jaber ${ }^{16}$, Caroline Bornstain ${ }^{17}$, Véronique Gaday ${ }^{18}$, René Robert ${ }^{19}$, Jean-Philippe Rigaud ${ }^{20}$, Raphaël Cinotti ${ }^{21}$, Mélanie Adda ${ }^{22}$, François Thomas ${ }^{23}$, Laure Calvet ${ }^{24}$, Marion Galon', Zoé Cohen-Solal', Alain Cariou ${ }^{25}$, Elie Azoulay ${ }^{1,26^{*}}$ and Famirea Study Group

\begin{abstract}
Purpose: Family members of patients who die in the intensive care unit (ICU) may experience symptoms of stress, anxiety, depression, posttraumatic stress disorder (PTSD), and/or prolonged grief. We evaluated whether grief symptoms were alleviated if the physician and the nurse in charge at the time of death sent the closest relative a handwritten condolence letter.

Methods: Multicenter randomized trial conducted among 242 relatives of patients who died at 22 ICUs in France between December 2014 and October 2015. Relatives were randomly assigned to receiving $(n=123)$ or not receiving $(n=119)$ a condolence letter. The primary endpoint was the Hospital Anxiety and Depression Score (HADS) at 1 month. Secondary endpoints included HADS, complicated grief (ICG), and PTSD-related symptoms (IES-R) at 6 months. Observers were blinded to group allocation.
\end{abstract}

Results: At 1 month, 208 (85.9\%) relatives completed the HADS; median score was 16 [IQR, 10-22] with and 14 [8-21.5] without the letter $(P=0.36)$. Although scores were higher in the intervention group, there were no significant differences regarding the HADS-depression subscale (8 [4-12] vs. $6[2-12]$, mean difference $1.1[-0.5$ to 2.6$] ; P=0.09$ ) and prevalence of depression symptoms (56.0 vs. 42.4\%, RR $0.76[0.57-1.00] ; P=0.05)$. At 6 months, 190 (78.5\%) relatives were interviewed. The intervention significantly increased the HADS (13 [7-19] vs. 10 [4-17.5], $P=0.04)$, HADSdepression subscale (6 [2-10] vs. $3[1-9], P=0.02)$, prevalence of depression symptoms (36.6 vs. $24.7 \%, P=0.05)$ and PTSD-related symptoms (52.4 vs. 37.1\%, $P=0.03$ ).

Conclusions: In relatives of patients who died in the ICU, a condolence letter failed to alleviate grief symptoms and may have worsened depression and PTSD-related symptoms.

Trial registration Clinicaltrials.gov Identifier: NCT02325297.

Keywords: Letter of condolence, Bereaved relatives, Grief symptoms 


\section{Introduction}

Among patients who die in hospital, the proportion dying in the intensive care unit (ICU) is increasing [1-3]. Studies have shown that more than half of bereaved relatives experience grief symptoms characterized by variably combined symptoms of anxiety, depression, stress, and complicated grief $[2,4-7]$. Interventions to improve grief symptoms are scarce. Two randomized controlled trials showed that improving communication during end-oflife care alleviated grief symptoms in relatives of patients who had died in the ICU $[8,9]$. However, no interventions implemented after the death have been evaluated.

After the patient's death, relatives often perceive an abrupt shift in their relationship with clinicians [10]. Failure to provide opportunities to say goodbye to the ICU team, with whom the relatives spent several intensely emotional days, may impair the grieving process [11, 12]. The duties of clinicians towards patients and relatives do not end when the patient dies. A letter of condolence from the clinician may benefit the grieving process in the relatives [13], as suggested by a qualitative study [14]. Such a letter may help the family accept the pain of bereavement and emphasize the value given by the clinician to the relationship with the patient and family [15]. A condolence letter may then alleviate grief symptoms, such as symptoms of anxiety, depression, PTSD, or complicated grief.

No study has properly assessed the impact of a condolence letter on grief symptoms in relatives. Sending a condolence letter is a simple and inexpensive means of communicating care and concern and might therefore benefit the relatives' well-being. We designed a multicenter randomized controlled trial to test the hypothesis that a condolence letter, compared to no condolence letter, alleviated grief symptoms in relatives of patients who had died in the ICU.

\section{Patients and methods}

\section{Study design and oversight}

From December 2014 to December 2015, we conducted a randomized, parallel-group trial in 22 hospitals in France (11 university and 11 non-university hospitals belonging to the French FAMIREA study group, "Appendix 1").

The study protocol was approved by the French ethics committee CPP Ile de France IV, Saint-Louis (April 15, 2014, \#2014/14SC) and French health authorities (CNIL MMS/VCS/AR149697 and CTTIRS \#14284). The protocol and statistical analysis plan have been published [16]. The trial was registered on clinicaltrial.gov on December 19,2014 and the first patient/next of kin was randomized on December 20, 2014. Informed consent was obtained from all participants.
The trial was overseen by an independent data and safety monitoring board. The funding source (Fondation de France) is an academic nonprofit organization that had no role in the study.

\section{Patients}

Patients were recruited in 22 ICUs belonging to FAMIREA and having considerable expertise in endof-life care [16, 17]. Eligibility criteria were age at least 18 years; at least one family visit prior to death; and an ICU stay of at least 2 days. Exclusion criteria were being pregnant and family not fluent in French.

\section{Relatives}

A single relative per patient was included. This relative was the designated healthcare proxy when available and the family member most involved with the ICU team otherwise. Informed consent was sought in the hours following patient's death. As per institutional review board requirement, the patient information sheet did not specify the nature of the intervention, but that a strategy to improve communication was being evaluated.

\section{Randomization}

Eligible patients/relatives were included by investigators in each ICU then randomly assigned in a 1:1 ratio to the intervention or control group. Randomization occurred within $24 \mathrm{~h}$ of the patient's death and was stratified according to study center on the basis of pre-established lists, with permutation blocks, whose size was concealed. A centralized Internet-based randomization procedure was used.

\section{Treatments}

We hypothesized that an intervention taking place after the patient's death would have a more positive impact as during this period bereaved family members describe feelings of abandonment, lack of comprehension, and a need for continuity [18]. All treatment decisions other than the condolence letter were made by the bedside physicians according to standard practice in each ICU. All families talked with the clinicians daily and attended an end-of-life conference [17]. Family involvement in decisions was tailored to each case on the basis of patient preferences, the family's preferred role as identified within the first ICU days, and an assessment by the ICU team [19-21].

In both groups, symptom control, timing of communication at the end-of-life, and implementation of treatment-limitation decisions were at the clinician's discretion. A letter of condolence was not part of standard care in the participating ICUs. 
In the intervention group, a condolence letter was prepared within 3 days after the patient's death, according to a guide developed by study investigators and based on their experience of qualitative interviews with bereaved families, literature review, and consensus among their multidisciplinary research team ("Appendix 2").

The physician and nurse in charge of the patient handwrote the letter and address on the envelope, which was kept in the physician's office until it was sent by standard mail 15 days after the patient's death. The randomization software sent an automatic reminder to mail the letter. A copy of the letter was filed in the case-report form. In brief, the letter covered the five following domains $[13,14,18]$ : recognize the death and name the deceased; mention a personal impression of the deceased; recognize the family member; offer help; and express sympathy ("Appendix 2").

In both groups, after randomization, the clinicians recorded all reactions or feedback (telephone calls, letters, visits, or other) from the relatives within 4 months following death.

\section{Study outcomes}

The telephone interviews with family members 30 days and 6 months after the patient's death were conducted by psychologists, sociologists, and research nurses blinded to study group.

The primary study outcomes were the Hospital Anxiety and Depression Scale (HADS) score $\geq 13$ and the prevalence of significant symptoms of both anxiety and depression (score $\geq 8$ on each subscale) after 1 month $[4,22,23]$. Secondary outcomes, evaluated after 6 months, were the HADS score, prevalence of HADS anxiety and depression subscale scores $\geq 8$, Impact of Event Scale Revised (IES-R) score, prevalence of significant PTSD-related symptoms (IES-R $\geq 26$ ) [2, 8, 16, 21, 24, 25], Inventory of Complicated Grief (ICG) score, and prevalence of high risk for complicated grief $(\mathrm{ICG} \geq 25)[5,16]$. The quality of dying and death as perceived by the relative was assessed using the CAESAR instrument [16].

The data in the tables and figures were collected prospectively. For each letter written, ICU specialists were asked to complete a questionnaire about their experience of writing condolence letters (supplemental Table 1).

\section{Statistical analysis}

All analyses were conducted according to a previously published statistical analysis plan [26]. On the basis of previous studies by our group [2, 4, 8, 16], we sought to detect a $30 \%$ HADS score decrease on day 30 and a decrease in the prevalence of anxiety and depression from $60 \%$ in controls to $42 \%$ with the condolence letter. Using a two-sided Chi square test, with $\alpha$ set at 0.05 , to obtain $90 \%$ power we needed 120 patients per group (240 in all).

No interim analysis was scheduled. The intent-to-treat approach was used. Continuous variables were described as median (interquartile range) and categorical variables as proportions. The primary outcome was compared between groups using the Wilcoxon rank-sum test for the total HADS score and the Chi square test, or exact Fisher test when appropriate, for prevalence of anxiety and depression.

Total scores on the HADS, IES-R, ICG, and CAESAR were compared between groups using the Wilcoxon rank-sum test. The prevalences of anxiety, depression, PTSD, and complicated grief were compared using the Chi square test, or exact Fisher test when appropriate; effect sizes were measured on mean difference or relative risk (RR), with their 95\% confidence interval (95\% $\mathrm{CI}$ ), respectively. We then used multivariable logistic regression models to compute adjusted odds ratios (ORs) for anxiety and depression, PTSD, or complicated grief symptoms at 1 and 6 months, with their 95\% CIs. We then used multivariable logistic regression models to compute adjusted odds ratios (ORs) for all outcome measures, namely HADS total scale $(\geq 13)$, anxiety and depression each ( $\geq 8)$, PTSD, or complicated grief symptoms at 1 and 6 months, with their 95\% CIs. Variables included in the multivariable model were those statistically significant in univariable analyses at the $5 \%$ level, or those selected for their predictive value based on previous reports. Variable selection used a stepwise selection procedure at the $5 \%$ level.

Effect sizes were measured on mean difference or relative risk (RR), with their 95\% confidence interval (95\% $\mathrm{CI}$ ), respectively. Sensitivity analyses were performed to handle missing outcomes, assuming that those patients had either a HADS value below or above 13 (supplemental Table 2).

All reported $P$ values are two-sided, and the significance level was 0.05. All analyses were performed on SAS software (SAS Inc., Cary, NC) and R 3.1.0 software (http://www.R-project.org/).

\section{Results}

\section{Patients and relatives}

Of the 242 included patients, 123 were randomly assigned to the intervention letter and 119 to the control group (Fig. 1). Interviews were conducted for 208 (86\%) relatives after 1 month (including 88 [42.3\%] living alone) and 190 $(78.5 \%)$ at 6 months. Baseline characteristics were evenly distributed between the two groups (Table 1). Treatmentlimitation decisions were taken for 202 (83.5\%) patients, with active involvement of the family in half the cases. The relatives were usually adult children $(n=83,40 \%)$ 


\section{5 patients assessed for eligibility}

- Not meeting inclusion criteria $(n=81)$

\section{2 patients randomized}

123 assigned to condolence letter

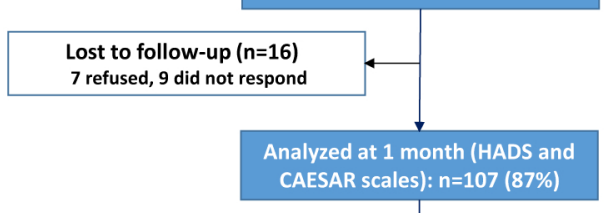

Lost to follow-up ( $\mathrm{n}=10)$

1 refused, 9 did not respond

Analyzed at 6 months (HADS, IES-

R and ICG): 97 (79\%)
119 assigned to standard of care

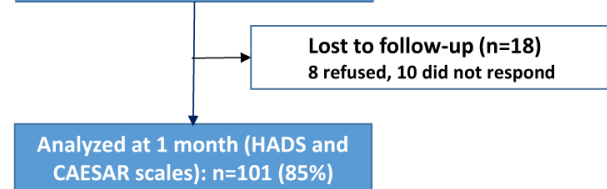

CAESAR scales): $n=101(85 \%)$

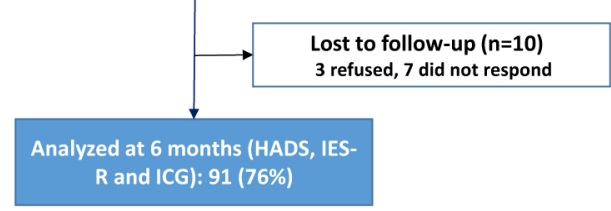

Fig. 1 Patient flow diagram

or spouses/partners $(n=74,35.6 \%)$. The CAESAR score indicated a good family experience of dying and death with a median score of $66(66$ [50-76] in the intervention group and 66 [52-78] in the control group).

\section{Interventions}

All intervention-group relatives were sent a condolence letter 2 weeks after the patient's death. All the letters complied with study guidelines and all included personal phrases and thoughts from physicians and nurses.

Feedback was received from 55 (44.7\%) interventiongroup relatives and $8(6.7 \%)$ controls $(P<0.0001)$ and was consistently positive regarding quality of care. Of the 55 intervention-group relatives who gave feedback, 50 did so to thank the clinician for the condolence letter. No relatives complained about the condolence letter.

ICU specialists reported that writing a condolence letter was neither difficult nor time consuming and that, although it did not particularly help them, it could help family members (supplemental Table 1).

\section{Primary outcome}

After 1 month, the HADS score was 16 [10-22] in the intervention group and 14 [8-21.5] in the control group $(P=0.36)$ (Table 2 ; Fig. 2$)$. The mean difference in HADS score was estimated at 0.77 (95\% CI -1.7 to +3.3 ). Although scores were higher in the intervention group, there were no significant differences in the HADS-depression subscale (8 [4-12] vs. $6[2-12]$, mean difference, $1.1,95 \% \mathrm{CI}-0.5$ to $+2.6 ; P=0.097)$ and prevalence of depression symptoms (56.0 vs. $42.4 \%$, $\mathrm{RR}=0.76,95 \% \mathrm{CI} 0.57-1.00 ; P=0.054)$. There were also no significant differences in the HADS-anxiety subscale (7 [4-11] vs 7 [4-12]; $P=0.92$ ) and prevalence of anxiety symptoms ( 47.7 vs $45.5 \% ; P=0.97)$.

\section{Secondary outcomes}

After 6 months, the HADS score was significantly worse in the intervention group (13 [7-19] vs. 10 [4-17.5], $P=0.04$ ) (Table 2; Fig. 2). The HADS-depression subscale score (6 [2-10] vs. 3 [1-9], mean difference of 1.4, 95\% CI -0.14 to $+2.90 ; P=0.026)$ and prevalence of depression symptoms ( 36.6 vs. $24.7 \%, P=0.05$ ) were also higher with the intervention. The intervention group had a higher prevalence of PTSD-related symptoms (52.4 vs. $37.1 \%, P=0.03$ ) but similar prevalence of complicatedgrief symptoms (37.6 vs. $29.2 \%, P=0.28$ ).

\section{Risk factors}

Table 3 reports the results of multivariate models of each outcome measure, where only variables selected by univariable analyses were introduced jointly. On the basis of multivariable analysis, a high 6-month HADS score ( $\geq 13$ ) was unexpectedly associated with the condolence letter (OR 2.17, 95\% CI 1.02-4.76), as well as patient's age (the lower, the higher the odds of increased HADS) and family education level (OR 2.50, 95\% CI 1.08-5.88), the spouse or partner status of the relative (OR 7.08, 95\% 
Table 1 Patients and family members' characteristics

\begin{tabular}{|c|c|c|}
\hline$N(\%)$ or median (25th-75th percentile) & Condolence letter & Control group \\
\hline Patients a randomization & $N=123$ & $N=119$ \\
\hline Age/female gender & $61(54-71) / 41(33.3 \%)$ & $61(54-66) / 44(37.0 \%)$ \\
\hline At least one comorbidity & $98(79.7 \%)$ & $100(84.3 \%)$ \\
\hline Intractable cancer & $37(30.1 \%)$ & $36(30.2 \%)$ \\
\hline Dependent or bedridden & $62(50.4 \%)$ & $56(47.1 \%)$ \\
\hline Dementia & $12(9.7 \%)$ & $10(8.4 \%)$ \\
\hline Life support was withheld/withdrawn & $99(80.5 \%)$ & $103(86.5 \%)$ \\
\hline \multicolumn{3}{|l|}{ Preferred role of relatives } \\
\hline Being only informed of the end-of-life decision & $31(25.3)$ & $41(34.4)$ \\
\hline To actively share the end-of-life decision & $66(53.6 \%)$ & $61(51.3 \%)$ \\
\hline Undetermined or unknown & $26(21.1)$ & $17(14.3)$ \\
\hline Patient intubated/sedated at the time of death & $72(58.5 \%) / 97(78.9 \%)$ & $65(54.6 \%) / 91(76.5 \%)$ \\
\hline Extubation in the last $48 \mathrm{~h}$ of life & $31(25.2 \%)$ & $36(30.2 \%)$ \\
\hline Family-clinician or intra-team conflicts & $9(7.3 \%)$ & $13(10.9 \%)$ \\
\hline \multicolumn{3}{|l|}{ Bedside presence at the time of death } \\
\hline Nurses & $81(65.9 \%)$ & $77(64.7 \%)$ \\
\hline Relatives & $75(61.0 \%)$ & $71(59.7 \%)$ \\
\hline Physicians & $38(30.9 \%)$ & $38(31.9 \%)$ \\
\hline Relatives interviewed at day 30 & $N=109$ & $N=99$ \\
\hline Age/female gender & $57[46-65.5] / 74(67.9 \%)$ & $56[44-64.5] / 71(71.7 \%)$ \\
\hline \multicolumn{3}{|l|}{ Relationship to the patient } \\
\hline Spouse & $42(38.5 \%)$ & $32(32.3 \%)$ \\
\hline Children & $43(39.4 \%)$ & $40(40.4 \%)$ \\
\hline Other & $24(22.0 \%)$ & $26(26.2 \%)$ \\
\hline Live alone after patient's death & $45(41.3 \%)$ & $43(43.4 \%)$ \\
\hline Rating of dying and death quality (CAESAR) & $66[50-76]$ & $66[52-78]$ \\
\hline
\end{tabular}

CAESAR quality of dying and death instrument developed by the FAMIREA study group [16]

\section{Table 2 Primary and secondary endpoints}

\begin{tabular}{|c|c|c|c|}
\hline$N(\%)$ or median (25th-75th) & $\begin{array}{l}\text { Condolence letter, } \\
N=123\end{array}$ & $\begin{array}{l}\text { Control group, } \\
N=119\end{array}$ & $P$ value \\
\hline Primary endpoint (day 30) & $N=109(88.6 \%)$ & $N=99(83.2)$ & \\
\hline Hospital Anxiety and Depression Scale (HADS) & $16[10-22]$ & $14[8-21]$ & 0.36 \\
\hline Depression subscale & $8[4-12]$ & $6[2-12]$ & 0.09 \\
\hline Relatives with symptoms of depression (subscale $\geq 8$ ) & $61(56.0 \%)$ & $42(42.4 \%)$ & 0.05 \\
\hline Secondary endpoints & $N=101(82.1 \%)$ & $N=89(74.8)$ & \\
\hline Hospital Anxiety and Depression Scale (HADS) at day 180 & $13(6-19)$ & $9(4-17)$ & 0.04 \\
\hline Depression subscale & $6(2-10)$ & $3(1-8)$ & 0.01 \\
\hline Relatives with symptoms of depression (subscale $\geq 8$ ) & $37(36.6 \%)$ & $22(24.7 \%)$ & 0.05 \\
\hline Impact of Events Scale-Revised at day 180 & $28[15-38]$ & $20[10-37]$ & 0.09 \\
\hline Relatives with PTSD-related symptoms (IES-R $\geq 26$ ) & $53(52.4 \%)$ & $33(37.1 \%)$ & 0.03 \\
\hline Inventory of complicated grief (ICG) at day 180 & $16[8-30]$ & $13[4-27]$ & 0.07 \\
\hline Relatives at high risk for complicated grief (ICG $\geq 25$ ) & $38(37.6 \%)$ & $24(27.0 \%)$ & 0.11 \\
\hline
\end{tabular}

CI 3.13-16.01) and the female gender of the relative (OR 3.02 , 95\% CI 1.25-7.30). By contrast, there was no statistical evidence that, when adjusting according to the prognostic factors (namely relative status and gender), the condolence letter modified the depression scale at 1 month (OR 1.85, 95\% CI 0.98-3.45; $P=0.06$ ). 
Units of Score

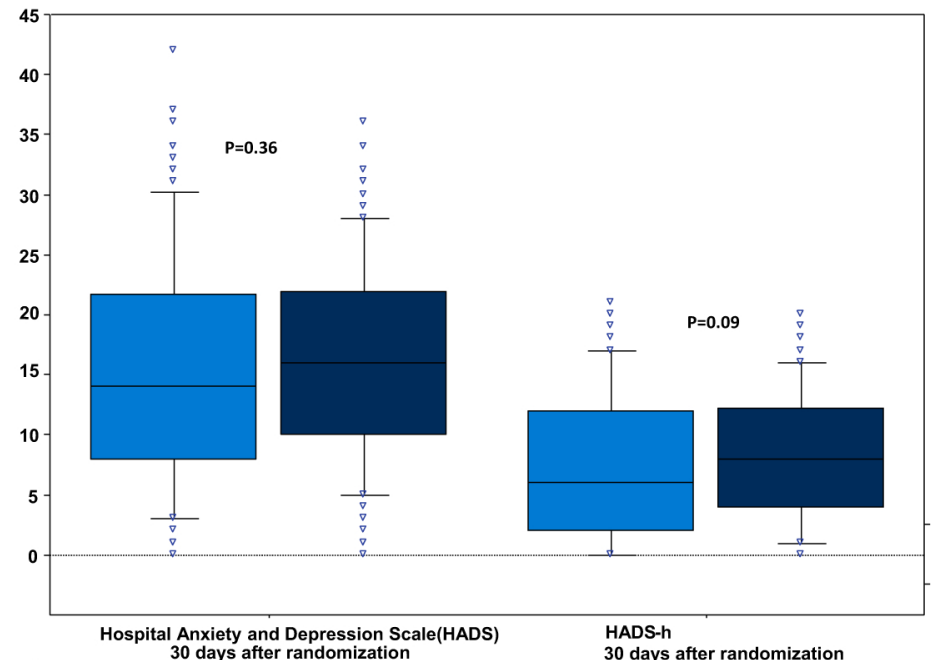

Units of Score 30 days after randomization

HADS-h

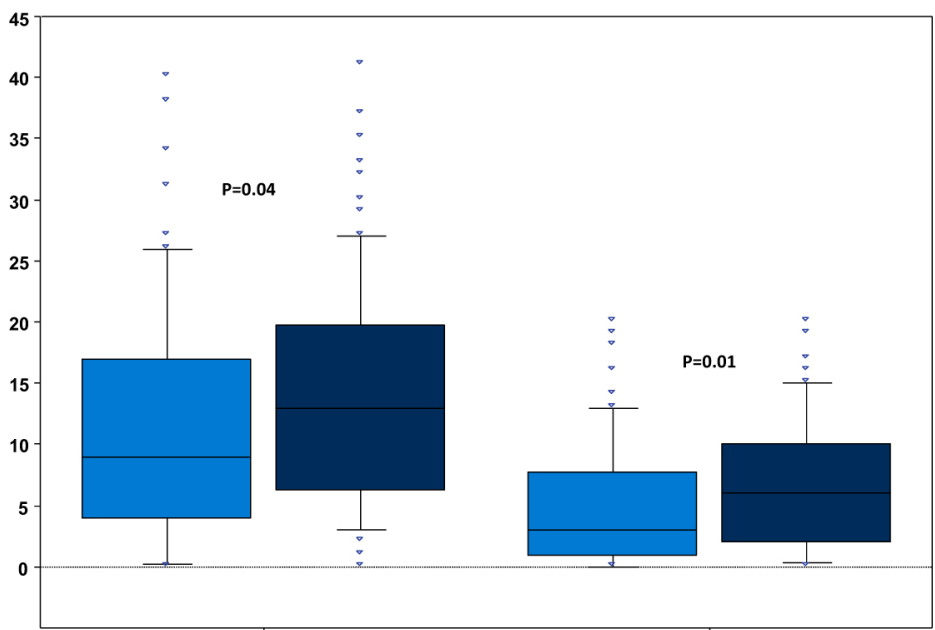

Hospital Anxiety and Depression Scale(HADS) HADS-depression subscale 180 days after randomization $\quad 180$ days after randomization
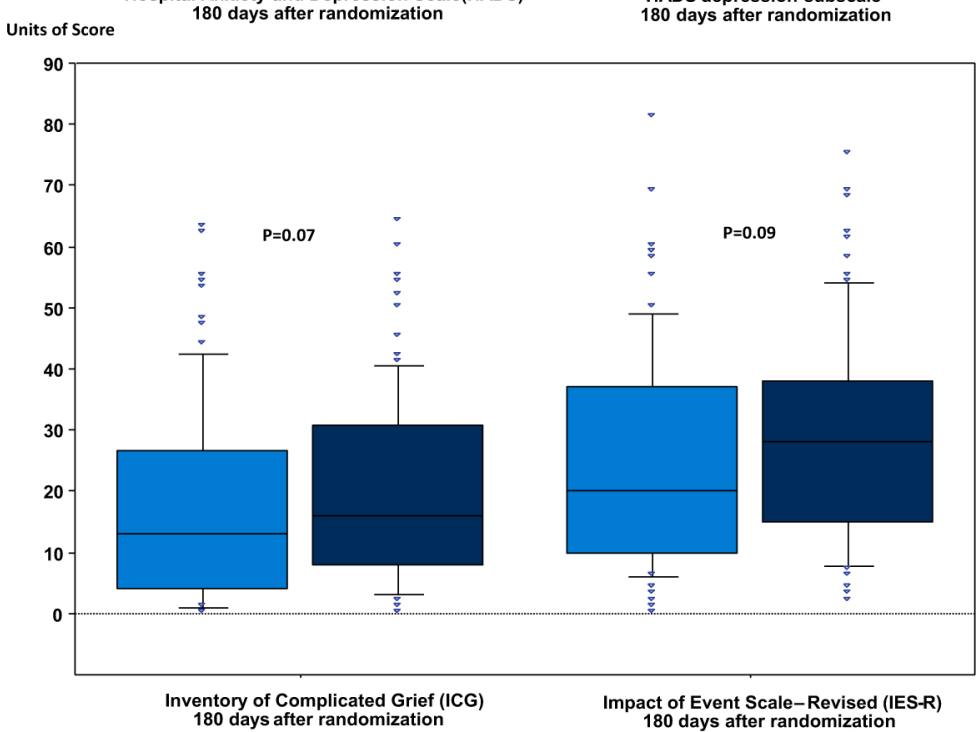

Fig. 2 Primary and secondary endpoints in intervention (dark gray bars) and control groups (light gray bars) 
Table 3 Independent predictors of primary and secondary outcomes by multivariable analyses

Odds ratio ( $95 \%$ confidence intervals)

$P$ value

Determinants of total HADS at day 30

Relative who was spouse or partner

$2.48(1.32-4.66)$

Relative of female gender

$2.19(1.17-4.10)$

CAESAR score

$0.99(0.98-1.01) /$ point

Determinants of depression symptoms at day 30

Relative who was spouse or partner

$5.16(2.61-10.18)$

$<0.0001$

Relative of female gender

$2.30(1.14-4.65)$

0.02

Randomized in control group (no condolence letter)

$0.54(0.29-1.02)$

0.06

Determinants of total HADS at day 180

Patient's age

$0.97(0.95-0.99) /$ year

0.04

Relative who was spouse or partner

$7.08(3.13-16.01)$

$<0.0001$

Relative of female gender

$3.02(1.25-7.30)$

0.01

High family education level

$0.40(0.17-0.93)$

0.03

Randomized in control group (no condolence letter)

$0.46(0.21-0.98)$

0.04

Determinants of depression subscale at day 180

Patient's age

$0.96(0.93-0.99) /$ year

0.01

Relative who was spouse or partner

$4.89(2.07-11.54)$

$<0.0001$

Relative live alone after patient's death

$3.85(1.59-9.30)$

$<0.0001$

Determinants of symptoms of complicated grief at day 180

Patient's age

$0.95(0.93-0.98) /$ year

$<0.0001$

Relative who was spouse or partner

$3.44(1.47-8.05)$

$<0.0001$

Relative live alone after patient's death

$4.33(1.81-10.38)$

$<0.0001$

Determinants of PTSD symptoms at day 180

Patient's age

$0.96(0.94-0.99) /$ year

Relative who was spouse or partner

$5.61(2.59-12.11)$

$<0.0001$

High family education level

$0.39(0.17-0.88)$

0.02

CAESAR quality of dying and death instrument developed by the FAMIREA study group [16

There was no evidence of any difference in terms of HADS less than 13 or at least 13 at day 30 across the randomized arms, and this was confirmed in all the sensitivity analyses but one that assumed a possibly unrealistic extreme case (supplemental Table 2).

\section{Discussion}

For clinicians providing care to dying patients, the wellbeing of the close family members is a central concern [19]. Caring for the family involves listening, eliciting and answering questions, showing that the family's role is valued, and addressing the specific needs of each family [27]. Psychiatric morbidity is common in relatives of patients who died in the ICU [28], the lack of interaction possibly hindering the grieving process [29]. The National Consensus Project for Quality Palliative Care has suggested that family care must continue after the patient's death by providing support to help the family cope during their grieving process [30,31]. We report the results of the first randomized clinical trial testing a clinician-led intervention that was implemented after the patient's death, at a time when the relatives no longer came to the ICU. A handwritten condolence letter sent 2 weeks after the death failed to alleviate grief symptoms. Unexpectedly, symptoms of depression and PTSD were worse with the intervention, albeit not significantly. Secondary outcomes, measured at 6 months, show a significant increased risk of developing depression and PTSD symptoms.

Our findings agree with earlier studies in that they were unexpected and opposite to the principal hypothesis $[2,8,9,16,32,33]$. The lack of effect of the intervention on the primary outcome (1-month HADS score) cannot be ascribed to insufficient power. The predicted impact of the intervention used for the sample size estimation was not overestimated, and therefore our study was adequately powered for the primary outcomes. When planning the study, we assumed that the intervention would alleviate grief symptoms. Instead, the relatives who received a condolence letter had an increased prevalence of symptoms of depression and PTSD-related symptoms. Moreover, by multivariable analysis, receiving 
a condolence letter was independently associated with HADS score at 6 months.

A key issue is whether the possible adverse effects of the intervention were related to the letter itself or to the 2-week interval between the patient's death and the letter. It has been suggested that a condolence letter or telephone call might help bereaved relatives [34]. In oncology, follow-up contact with the relatives (attending funerals, visiting at home, calling on the telephone, or sending a condolence letter) is frequently offered to acknowledge the loss, express sympathy and support, and offer opportunities to answer questions about end-oflife care [35-37]. In our study, the letter may have been perceived by the relatives as an unwelcome reminder of a painful period characterized by feelings of failure and helplessness, which are known contributors to depression [38]. Alternatively, for relatives still requiring the protection afforded by denial, the letter may have weakened that psychological position, thereby exacerbating symptoms of depression and PTSD [12]. However, in a recent qualitative study about reasons to participate in bereavement research, bereaved relatives reported wanting to thank the ICU staff members and to continue receiving support and care from them [18]. In the primary-care setting, nearly half the respondents to a survey reported expecting a telephone call from their family physician shortly after the death and that any mark of sympathy from the physician was greatly appreciated [39].

A condolence letter alone may be insufficient to provide benefits. Complex interventions to support bereaved relatives have been evaluated in the ICU or palliative-care setting [9, 32, 33]. Family members may have expected the letter to be followed by further support and felt disappointment when none was provided. However, of the 123 intervention-group patients, $50(40 \%)$ thanked the clinician for the letter. However, studies of complex interventions produced conflicting results. For instance, in a randomized controlled trial by our group, an end-of-life family conference and brochure decreased the prevalences of symptoms of anxiety, depression, and PTSD [9, $32,33]$. In another randomized controlled trial, having a facilitator support communication between ICU clinicians and families, tailor interactions to each family's needs, and mediate conflict produced no benefits at the 3 -month evaluation, although the prevalence of symptoms of depression was decreased after 6 months [9].

Importantly, two trials reported unexpected effects from end-of-life interventions. For instance, in a randomized trial, Curtis et al. assessed the effects of an 8-session, simulation-based, communication skills intervention for internal medicine and nurse practitioner trainees on patient- and family-reported outcomes [32]. The intervention was associated with significantly increased depression scores. More recently, Carson et al. conducted a multicenter randomized clinical trial in patients requiring 7 days of mechanical ventilation [33]. They assessed the impact of structured family meetings led by palliative care specialists, and provision of an informational brochure, on surrogate decision-makers. PTSD symptoms were higher in the intervention group compared with the control group. In the present trial, the finding that a condolence letter failed to alleviate grief symptoms and may have worsened depression and PTSD-related symptoms in bereaved relatives is in line with these trials. Interestingly, the three studies share common points but also striking differences. All are large multicenter trials that targeted grief symptoms in family members of ICU patients, and all reported unexpected results as the intervention did not improve outcomes but was associated with increased depression or PTSDrelated symptoms. However, in the present trial randomization occurred at the time of death and the intervention occurred 2 weeks after patient's death, relatives having left the hospital. Moreover, this study did not involve palliative care specialists. Our data raise concern that rather than being helpful to bereaved relatives, involvement of physicians in bereavement care in the form a unique condolence letter may in fact be inappropriate [40].

Strengths of our study include the multicenter design and full compliance with the intervention. The characteristics of the patients and relatives and the severity of grief symptoms are consistent with earlier work $[9,16$, 33]. The follow-up rate of relatives was very high. The statistical analysis plan was published before recruitment was completed, eliminating all risk of analytical bias [26]. The interviewers who collected the primary and secondary outcomes were blinded to group allocation. Although the HADS score might be influenced by observer bias [8, $9,33]$, it is a well-validated outcome measure. The risk of bias was minimized by using central randomization and the risk of patient selection by effective concealment of the randomization scheme. The results have a high degree of external validity, since the centers belong to a large research group including university and non-university hospitals $[5,6,8,16]$.

Our study has several limitations. All participating ICUs were in France, which may limit the general applicability of our findings, as end-of-life care and bereavement follow-up vary widely across countries. Furthermore, all ICUs belonged to a group that had a special interest in family-centered care. The intervention was not fully standardized: the clinicians followed guidelines for the letter but otherwise were free to write what they wanted to. Nevertheless, all letters complied with the guidelines. The psychological status of the relatives at the time they received the condolence letter was 
not evaluated. This factor may influence the effect of a condolence letter, and the kinetics of grieving remain unclear $[9,32,33]$. Also, a condolence letter alone may have been insufficient to provide expected benefits. However, if the condolence letter had only been one part of a more complex intervention, it would have been difficult to distinguish what specific element of the intervention had an impact of relatives' grief symptoms. We chose a simple intervention in order to fully appreciate its impact on relatives' experience. Moreover, a careful analysis of the letters sent to the relatives showed that these letters included components of each of the five recommended domains, suggesting that the intervention was provided at the same dose for each participating family member. Last, our primary outcome was collected after only 1 month and the secondary outcomes after 6 months. Studies of outcomes after 1 or 2 years would be of interest.

In conclusion, in our trial, a condolence letter did not alleviate grief symptoms in relatives of patients who died in the ICU. Unexpectedly, the intervention was associated with higher prevalences of symptoms of depression and PTSD. Our findings do not support the sending of a condolence letter to bereaved relatives as the sole, routine post-ICU intervention.

\section{Acknowledgments}

We would like to thank Marine Chaize and Frédéric Pochard for their advice and thoughtful comments regarding the study.

Contributors: Virginie Lemiale MD, Sandrine Vallade MD from Assistance Publique, Hôpitaux de Paris, Saint-Louis University Hospital, Paris, France. Guillaume Géri MD, Wulfran Bougouin MD, Michel Arnaout MD, Lara Zafrani MD, Shirley Spagnolo MD, and Olivier Passouant MD from Assistance Publique, Hôpitaux de Paris, Cochin University Hospital, Paris, France. Gérald Choukroun MD and Laura Federicci MD from Sud Francilien Hospital, Corbeil-Essonnes, France. Alexandre Herbland MD and Maxime Leloup MD from La Rochelle Hospital, La Rochelle, France. Amelie Bazire MD and Pierre Bailly MD from Cavale Blanche University Hospital, Brest, France. Thomas Baudry MD, Romain Hernu MD, and Sylvie de la Salle RN from Hospices Civils de Lyon, Edouard Herriot Hospital and Lyon Est University, Lyon, France. Alexandre Demoule MD, PhD; Julien Mayaux MD from Assistance Publique, Hôpitaux de Paris, La Pitié-Salpêtrière University Hospital, Paris, France. Sébastien Cavelot (CRA) and Sybille Merceron MD from Versailles Hospital, Versailles, France. Arnaud Follin MD, Gersande Fave MD, Anne-Laure Constant MD, and Vibol Chhor MD from Assistance Publique, Hôpitaux de Paris, Hôpital Européen Georges Pompidou, Paris, France. Julie Carr MD, Audrey De Jong MD, and Albert Prades RN from Saint Eloi University Hospital, Montpellier, France. Vincent Francois MD from Le Raincy-Montfermeil Hospital, Montfermeil, France. Marie Thuong MD from René-Dubos Hospital, Pontoise, France. Séverin Cabason MD from Poitiers University Hospital and Poitiers University, Poitiers, France. Stéphanie Gelinotte MD from Dieppe Hospital, Dieppe, France. Laurent Papazian MD PhD, JeanMarie Forel MD, Christophe Guervilly MD, Sami Hraiech MD, PhD, Samuel Lehingue MD, Romain Rambaud MD, Elisa Marchi MD, and Pierre Esnault MD from Hôpital Nord University Hospital, Marseille, France. Michel Slama MD, PhD, Julien Maizel MD, and Thierry Soupison MD from Sud Amiens University Hospital, Amiens, France. Bertrand Souweine MD, PhD from Gabriel Montpied University Hospital, Clermont-Ferrand, France.

\section{Compliance with ethical standards}

\section{Funding}

Grant from the Fondation de France, a non-profit institution.

\section{Appendix 1: Participating ICUs}

\begin{tabular}{|c|c|c|c|c|}
\hline & $\begin{array}{l}\text { Investigator } \\
\text { name }\end{array}$ & City & Hospital & $\begin{array}{l}\text { Type } \\
\text { of intensive } \\
\text { care }\end{array}$ \\
\hline 1 & Marion Venot & Paris & Saint Louis & $\begin{array}{l}\text { Medical inten- } \\
\text { sive care }\end{array}$ \\
\hline 2 & $\begin{array}{c}\text { Benoît Cham- } \\
\text { pigneulle }\end{array}$ & Paris & Cochin & $\begin{array}{l}\text { Medical inten- } \\
\text { sive care }\end{array}$ \\
\hline 3 & $\begin{array}{l}\text { Maité Gar- } \\
\text { rouste }\end{array}$ & Paris & Saint Joseph & $\begin{array}{l}\text { General inten- } \\
\text { sive care }\end{array}$ \\
\hline 4 & Gilles Troche & $\begin{array}{c}\text { Le Chesnay- } \\
\text { Versailles }\end{array}$ & André Mignot & $\begin{array}{l}\text { General inten- } \\
\text { sive care }\end{array}$ \\
\hline 5 & Olivier Guisset & Bordeaux & Saint André & $\begin{array}{l}\text { Medical inten- } \\
\text { sive care }\end{array}$ \\
\hline 6 & Anne Renault & Brest & $\begin{array}{l}\text { Cavale } \\
\text { Blanche }\end{array}$ & $\begin{array}{l}\text { Medical inten- } \\
\text { sive care }\end{array}$ \\
\hline 7 & $\begin{array}{l}\text { Laurent } \\
\text { Argaud }\end{array}$ & Lyon & $\begin{array}{l}\text { Edouard Her- } \\
\text { riot }\end{array}$ & $\begin{array}{l}\text { Medical inten- } \\
\text { sive care }\end{array}$ \\
\hline 8 & Mélanie Adda & Marseille & Hôpital Nord & $\begin{array}{l}\text { Medical inten- } \\
\text { sive care }\end{array}$ \\
\hline 9 & $\begin{array}{l}\text { Jean-Philippe } \\
\text { Rigaud }\end{array}$ & Dieppe & CH de Dieppe & $\begin{array}{l}\text { General inten- } \\
\text { sive care }\end{array}$ \\
\hline 10 & $\begin{array}{l}\text { Isabelle } \\
\text { Vinatier }\end{array}$ & $\begin{array}{l}\text { La Roche-sur- } \\
\text { Yon }\end{array}$ & Les Oudairies & $\begin{array}{l}\text { General inten- } \\
\text { sive care }\end{array}$ \\
\hline
\end{tabular}

\section{Author details}

${ }^{1}$ Assistance Publique, Hôpitaux de Paris, Saint-Louis University Hospital, Famiréa Research Group, Paris, France. ${ }^{2}$ ECSTRA Team, Biostatistics and Clinical Epidemiology, UMR 1153, INSERM, Paris Diderot Sorbonne University and Service de Biostatistique et Information Médicale AP-HP, Hôpital Saint-Louis, Paris, France. ${ }^{3}$ Assistance Publique, Hôpitaux de Paris, Cochin University Hospital, Paris, France. ${ }^{4}$ Victor Dupouy Hospital Argenteuil, France. ${ }^{5}$ Sud Francilien Hospital, Corbeil-Essonnes, France. ${ }^{6}$ La Rochelle Hospital, La Rochelle, France. ${ }^{7}$ Cavale Blanche University Hospital, Brest, France. ${ }^{8}$ Saint Joseph Hospital, Paris, France. ${ }^{9}$ Hospices Civils de Lyon, Edouard Herriot Hospital, Lyon Est University, Lyon, France. ${ }^{10}$ Assistance Publique, Hôpitaux de Paris, Saint-Louis University Hospital, Paris, France. ${ }^{11}$ Assistance Publique, Hôpitaux de Paris, La Pitié-Sal pêtrière University Hospital, Paris, France. ${ }^{12}$ Saint André University Hospital, Bordeaux, France. ${ }^{13}$ Les Oudairies Hospital, La Roche sur Yon, France. ${ }^{14}$ Versailles Hospital, Versailles, France. ${ }^{15}$ Assistance Publique, Hôpitaux de Paris, Hôpital Européen Georges Pompidou, Paris, France. ${ }^{16}$ Saint Eloi University Hospital, and Inserm U-1046, Montpellier, France. ${ }^{17}$ Le Raincy-Montfermeil Hospital, Montfermeil, France. ${ }^{18}$ René-Dubos Hospital, Pontoise, France. ${ }^{19}$ Poitiers University Hospital and Poitiers University and Inserm CIC 1402, Poitiers, France. ${ }^{20}$ Dieppe Hospital, Dieppe, France. ${ }^{21}$ Hôtel Dieu University Hospital, Nantes, France. ${ }^{22}$ Assistance Publique, Hôpitaux de Marseille, Hôpital Nord University Hospital, Marseille, France. ${ }^{23}$ Sud Amiens University Hospital, Amiens, France. ${ }^{24}$ Gabriel Montpied University Hospital, Clermont-Ferrand, France. ${ }^{25}$ Assistance Publique, Hôpitaux de Paris, Cochin University Hospital, Paris Descartes University, Paris, France. ${ }^{26}$ Medical Intensive Care Unit, Hôpital Saint-Louis, ECSTRA Team, and Clinical Epidemiology, UMR 1153 (Center of Epidemiology and Biostatistics Sorbonne Paris Cité, CRESS), INSERM, Paris Diderot Sorbonne University , 1 rue Claude Vellefaux, 75010 Paris, France. 


\begin{tabular}{|c|c|c|c|c|}
\hline & $\begin{array}{l}\text { Investigator } \\
\text { name }\end{array}$ & City & Hospital & $\begin{array}{l}\text { Type } \\
\text { of intensive } \\
\text { care }\end{array}$ \\
\hline 11 & Samir Jaber & Montpellier & Saint Eloi & $\begin{array}{l}\text { General inten- } \\
\text { sive care }\end{array}$ \\
\hline 12 & Marina Thirion & १ Argenteuil & $\begin{array}{l}\text { CHVictor } \\
\text { Dupouy }\end{array}$ & $\begin{array}{l}\text { General inten- } \\
\text { sive care }\end{array}$ \\
\hline 13 & Olivier Lesieur & - La Rochelle & $\begin{array}{l}\mathrm{CH} \text { de la } \\
\text { Rochelle }\end{array}$ & $\begin{array}{l}\text { General inten- } \\
\text { sive care }\end{array}$ \\
\hline 14 & René Robert & Poitiers & $\begin{array}{l}\text { CHU de } \\
\text { Poitiers }\end{array}$ & $\begin{array}{l}\text { Medical inten- } \\
\text { sive care }\end{array}$ \\
\hline 15 & $\begin{array}{l}\text { Raphaël } \\
\text { Cinotti }\end{array}$ & Nantes & $\begin{array}{l}\text { CHU de } \\
\text { Nantes }\end{array}$ & $\begin{array}{l}\text { Surgical inten- } \\
\text { sive care }\end{array}$ \\
\hline 16 & Laure Calvet & $\begin{array}{l}\text { Clermont Fer- } \\
\text { rand }\end{array}$ & $\begin{array}{c}\text { CHU Gabriel } \\
\text { Montpied }\end{array}$ & $\begin{array}{l}\text { General inten- } \\
\text { sive care }\end{array}$ \\
\hline 17 & $\begin{array}{l}\text { Caroline } \\
\text { Bornstain }\end{array}$ & Montfermeil & CHI Le Raincy & $\begin{array}{l}\text { General inten- } \\
\text { sive care }\end{array}$ \\
\hline 18 & Marion Gilber & $\begin{array}{l}\text { tCorbeil- } \\
\text { Essones }\end{array}$ & $\begin{array}{l}\text { CH Sud-Fran- } \\
\text { cilien }\end{array}$ & $\begin{array}{l}\text { General inten- } \\
\text { sive care }\end{array}$ \\
\hline 19 & $\begin{array}{l}\text { Véronique } \\
\text { Gaday }\end{array}$ & Pontoise & $\begin{array}{l}\text { CH René } \\
\text { Dubos }\end{array}$ & $\begin{array}{l}\text { General inten- } \\
\text { sive care }\end{array}$ \\
\hline 20 & $\begin{array}{l}\text { Alexandre } \\
\text { Demoule }\end{array}$ & Paris & $\begin{array}{c}\text { La Pitié-Sal- } \\
\text { pêtrière }\end{array}$ & $\begin{array}{l}\text { Medical inten- } \\
\text { sive care }\end{array}$ \\
\hline 21 & $\begin{array}{l}\text { François } \\
\text { Thomas }\end{array}$ & Amiens & $\begin{array}{l}\text { CHU Amiens- } \\
\text { Picardie } \\
\text { Hôpital Sud }\end{array}$ & $\begin{array}{l}\text { Nephrology } \\
\text { intensive } \\
\text { care }\end{array}$ \\
\hline 22 & Julien Massot & Paris & HEGP & $\begin{array}{l}\text { Anesthesia- } \\
\text { surgical } \\
\text { intensive } \\
\text { care }\end{array}$ \\
\hline
\end{tabular}

\section{Appendix 2}

Recommendations for writing a condolence letter and examples

Why write a condolence letter?

- To help family members in the bereavement process: the letter helps relatives feel recognized in their pain and not abandoned by the hospital team,

- to help family members manage potential feelings of anger or lack of understanding following an unexpected death,

- to help the physician take stock of the patient's death,

- to bring closure to the relationship between caregivers and the families of the deceased patient.

\section{Recommendations for writing a condolence letter}

The condolence letter must be handwritten

- Avoid superficial expressions like "I know what you're feeling".

- Don't write too formal a letter!

- Please be sure to integrate the following five domains.
1. Recognize the death-name the deceased

- The importance of naming the deceased.

- Reduces the feeling of loneliness of the family member.

2. Talk about the deceased

- If possible, personality, age, interests (sports, religion...).

- If possible, mention a specific memory of the deceased.

- If possible, mention the relationship of the deceased with the family member.

3. Recognize the family member

- Personality, strengths (to recognize a potential for coping effectively).

- Mention what the family member did for or with the patient in ICU (frequent visits, participating in care, etc.).

- Or even the relationship of the family member with the ICU team.

4. Offer help: the possibility of contacting you

- Be specific (phone number of the ICU).

5. Express your sympathy (conclusion)

- Symbolize a shared emotion.

\section{Examples}

1. Recognize the death and name the deceased

I send you my sincere condolences on the death of your sister, Alison Smith. Natalie, who was your sister's nurse, joins me in expressing our sympathy.

\section{Mention the deceased}

(a) Patient who was conscious and able to communicate:

We had the opportunity to get to know your brother during his stay in our unit. He was very brave. His smile and his words touched us often. His caregivers were always happy to go into his room.

Or

We had the opportunity to get to know your mother during her stay in our unit. She was very brave. We understood her need to be cared for and reassured and we hope we were able to comfort her in the difficult moments.

(b) Patient who was conscious but had difficulty communicating:

We had the opportunity to get to know your brother during his stay in our unit. He seemed very brave. He 
tried to communicate with us in different ways, for example using the whiteboard we gave him, even though we know it was sometimes difficult for him.

(c) Patient who was never conscious in the ICU.

We did not have the opportunity to really get to know your aunt and we regret that. However, thanks to her family members, we could see that she was a kind and brave woman and we did our best to care for her and help her with kindness and respect.

3. Recognize the family member.

You were very present during his stay, ready to assist and be present for your brother. In my experience as a physician, I believe that the presence and support of a family member brings peace and serenity to those who are at the end of life.

4. Offer help.

I remain at your service if you wish to ask any questions or simply discuss your brother's stay in intensive care. Please feel free to call us at [telephone number].

\section{Express your sympathy (conclusion).}

\author{
We send you our warmest thoughts, \\ Dr. Doe.
}

\section{References}

1. Angus DC, Barnato AE, Linde-Zwirble WT et al (2004) Use of intensive care at the end of life in the United States: an epidemiologic study. Crit Care Med 32(3):638-643

2. Long AC, Kross EK, Davydow DS, Curtis JR (2014) Posttraumatic stress disorder among survivors of critical illness: creation of a conceptual model addressing identification, prevention, and management. Intensive Care Med 40(6):820-829

3. Lautrette A, Garrouste-Orgeas M, Bertrand PM et al (2015) Respective impact of no escalation of treatment, withholding and withdrawal of lifesustaining treatment on ICU patients' prognosis: a multicenter study of the Outcomerea Research Group. Intensive Care Med 41(10):1763-1772

4. Pochard F, Azoulay E, Chevret S et al (2001) Symptoms of anxiety and depression in family members of intensive care unit patients: ethical hypothesis regarding decision-making capacity. Crit Care Med 29(10):1893-1897

5. Kentish-Barnes N, Chaize M, Seegers V et al (2015) Complicated grief after death of a relative in the intensive care unit. Eur Respir J 45(5):1341-1352

6. Azoulay E, Pochard F, Kentish-Barnes N et al (2005) Risk of post-traumatic stress symptoms in family members of intensive care unit patients. Am J Respir Crit Care Med 171(9):987-994
7. Kentish-Barnes N, Prigerson HG (2016) Is this bereaved relative at risk of prolonged grief? Intensive Care Med 42(8):1279-1281

8. Lautrette A, Darmon M, Megarbane B et al (2007) A communication strategy and brochure for relatives of patients dying in the ICU. N Engl Med 356(5):469-478

9. Curtis JR, Treece PD, Nielsen EL et al (2016) Randomized trial of communication facilitators to reduce family distress and intensity of end-of-life care. Am J Respir Crit Care Med 193(2):154-162

10. Nelson JE, Puntillo KA, Pronovost PJ et al (2010) In their own words: patients and families define high-quality palliative care in the intensive care unit. Crit Care Med 38(3):808-818

11. Prigerson HG, Maciejewski PK, Reynolds CF 3rd et al (1995) Inventory of Complicated Grief: a scale to measure maladaptive symptoms of loss. Psychiatry Res 59(1-2):65-79

12. Maciejewski PK, Zhang B, Block SD, Prigerson HG (2007) An empirical examination of the stage theory of grief. JAMA 297(7):716-723

13. Bedell SE, Cadenhead K, Graboys TB (2001) The doctor's letter of condolence. N Engl J Med 344(15):1162-1164

14. Morris SE, Block SD (2015) Adding value to palliative care services: the development of an institutional bereavement program. J Palliat Med 18(11):915-922

15. Kane RL, Klein SJ, Bernstein L, Rothenberg R (1986) The role of hospice in reducing the impact of bereavement. J Chronic Dis 39(9):735-742

16. Kentish-Barnes N, Seegers V, Legriel S et al (2016) CAESAR: a new tool to assess relatives' experience of dying and death in the ICU. Intensive Care Med 42(6):995-1002

17. Lautrette A, Ciroldi M, Ksibi H, Azoulay E (2006) End-of-life family conferences: rooted in the evidence. Crit Care Med 34(11 Suppl):S364-S372

18. Kentish-Barnes N, McAdam JL, Kouki S et al (2015) Research participation for bereaved family members: experience and insights from a qualitative study. Crit Care Med 43(9):1839-1845

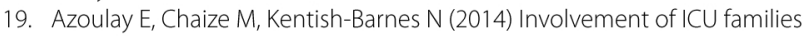
in decisions: fine-tuning the partnership. Ann Intensive Care. 4(37):37

20. Curtis JR, Sprung CL, Azoulay E (2014) The importance of word choice in the care of critically ill patients and their families. Intensive Care Med 40(4):606-608

21. Jabre P, Tazarourte K, Azoulay E et al (2014) Offering the opportunity for family to be present during cardiopulmonary resuscitation: 1-year assessment. Intensive Care Med 40(7):981-987

22. Zigmond AS, Snaith RP (1983) The hospital anxiety and depression scale. Acta Psychiatr Scand 67(6):361-370

23. Ghesquiere AR, Park M, Bogner HR, Greenberg RL, Bruce ML (2014) The effect of recent bereavement on outcomes in a primary care depression intervention study. Am J Geriatr Psychiatry 22(12):1555-1564

24. Jones C (2014) What's new on the post-ICU burden for patients and relatives? Intensive Care Med 39(10):1832-1835

25. Herridge MS, Moss M, Hough CL et al (2016) Recovery and outcomes after the acute respiratory distress syndrome (ARDS) in patients and their family caregivers. Intensive Care Med 42(5):725-738

26. Kentish-Barnes N, Chevret S, Azoulay E (2016) Impact of the condolence letter on the experience of bereaved families after a death in intensive care: study protocol for a randomized controlled trial. Trials 17(1):102

27. Curtis JR, White DB (2008) Practical guidance for evidence-based ICU family conferences. Chest 134(4):835-843

28. Siegel MD, Hayes E, Vanderwerker LC, Loseth DB, Prigerson HG (2008) Psychiatric illness in the next of kin of patients who die in the intensive care unit. Crit Care Med 36(6):1722-1728

29. Cuthbertson SJ, Margetts MA, Streat SJ (2000) Bereavement follow-up after critical illness. Crit Care Med 28(4):1196-1201

30. Ferrell B, Connor SR, Cordes A et al (2007) The national agenda for quality palliative care: the National Consensus Project and the National Quality Forum. J Pain Symptom Manag 33(6):737-744

31. National Consensus Project for Quality Palliative Care (2004) Clinical Practice Guidelines for quality palliative care, executive summary. J Palliat Med 7(5):611-627

32. Curtis JR, Back AL, Ford DW et al (2013) Effect of communication skills training for residents and nurse practitioners on quality of communication with patients with serious illness: a randomized trial. JAMA $310(21): 2271-2281$ 
33. Carson SS, Cox CE, Wallenstein S et al (2016) Effect of palliative care-led meetings for families of patients with chronic critical illness: a randomized clinical trial. JAMA 316(1):51-62

34. Charlton R, Dolman E (1995) Bereavement: a protocol for primary care. $\mathrm{Br}$ J Gen Pract 45(397):427-430

35. Corn BW, Shabtai $E_{1}$ Merimsky $O$ et al (2010) Do oncologists engage in bereavement practices? A survey of the Israeli Society of Clinical Oncology and Radiation Therapy (ISCORT). Oncologist 15(3):317-326

36. Chau NG, Zimmermann C, Ma C, Taback N, Krzyzanowska MK (2009) Bereavement practices of physicians in oncology and palliative care. Arch Intern Med 169(10):963-971

37. Kusano AS, Kenworthy-Heinige T, Thomas CR Jr (2012) Survey of bereavement practices of cancer care and palliative care physicians in the Pacific Northwest United States. J Oncol Pract 8(5):275-281
38. Sullivan DR, Liu X, Corwin DS et al (2012) Learned helplessness among families and surrogate decision-makers of patients admitted to medical, surgical, and trauma ICUs. Chest 142(6):1440-1446

39. Dangler LA, O'Donnell J, Gingrich C, Bope ET (1996) What do family members expect from the family physician of a deceased loved one? Fam Med 28(10):694-697

40. Ghesquiere AR, Patel SR, Kaplan DB, Bruce ML (2014) Primary care providers' bereavement care practices: recommendations for research directions. Int J Geriatr Psychiatry 29(12):1221-1229 